\title{
Implementation of Online Arabic Learning With the Help of WhatsApp Media During the Covid-19
}

\author{
$1^{\text {st }}$ Yogia Prihartini ${ }^{1}, 2^{\text {nd }}$ Wahyudi Buska ${ }^{2}, 3^{\text {rd }}$ Yusmarni $^{3}$ \\ \{yogia_prihartini@uinjambi.ac.id ${ }^{1}$,wahyudi@uinjambi.ac.id ${ }^{2}$,yusmarni@uinjambi.ac.id ${ }^{3}$ \} \\ UIN Sulthan Thaha Saifuddin Jambi ${ }^{1,2,3}$
}

\begin{abstract}
This study aims to describe the implementation of the online Arabic learning process using WhatsApp media during the covid 19 at UIN Sulthan Thaha Saifuddin Jambi. This type of research is descriptive qualitative research with phenomenological research..The results of the study show that Arabic language lecturers have used WhatsApp as a learning medium in supporting online learning activities by utilizing various available features such as photo, video, document and video call features. In the implementation of the use of WhatsApp as a learning medium there are several obstacles, namely cellphones, internet quotas, lack of interaction, difficulty in knowing the seriousness of students' learning, lack of interest in student learning, limited time, and difficulty in understanding the material provided, and in this study describe solutions. This was done to overcome the obstacles that occur from the use of WhatsApp as a learning medium during the Covid-19 pandemic.
\end{abstract}

Keywords: implementation, Arabic learning, application, WhatsApp media.

\section{Introduction}

Learning media has a very important role for the success of student learning [1]. With the use of learning media will encourage student involvement in the learning process, and make it easier for students to understand the material being studied. The use of learning media greatly influences student responses, with learning media the learning process will be more effective, active and creative and can foster student interest and motivation to learn [2]. Therefore, the role of a teacher today is very much needed, not only professional and competent in their field, but able to increase their knowledge, master and develop learning media, and be able to improve learning achievement in accordance with competency standards, basic competencies and indicators.

WhatsApp social media are now widely used by various groups, especially students. WhatsApp as a chat application that can send text messages, pictures, sounds, locations and videos to other people using any type of smartphone [3]. The WhatsApp Messenger application usually uses a $3 \mathrm{G} / 4 \mathrm{G}$ or $\mathrm{WiFi}$ connection for data communication. By using WhatsApp, one can chat online, share files, and exchange information. WhatsApp is an Instant Messaging technology such as SMS with the help of internet data with more attractive supporting features and is the most popular social media that can be used as a communication medium [4]. The WhatsApp Messenger application has the potential to be used as a learning tool. 
Distance learning carried out is lacking in terms of interaction, teachers cannot directly monitor the learning process and limited ability to receive material delivered online with instant messaging applications such as WhatsApp media [5]. This is because distance learning is still considered no better than conventional direct learning, students cannot ask the teacher directly if there is material that is not understood through virtual explanations. The use of social media that is often used in online or distance learning situations in the midst of the current pandemic is WhatsApp media.

WhatsApp media is an application designed to facilitate communication in the midst of current technological developments [6]. WhatsApp is part of social media that make it easy and allows all users to share information [7]. The use of WhatsApp has been used by various groups of people because of its easy use. In line with Jumiatmoko's opinion that WhatsApp is an internet-based application that makes it easy for users to communicate with the available features and is the most popular social media used in communicating. 83\% of 171 million internet users are WhatsApp users [8]. WhatsApp is a means of communicating by exchanging information both text messages, pictures, videos and even telephones. From this opinion, it can be seen that WhatsApp provides convenience in conveying information. The use of WhatsApp will make it easier for users to convey information more quickly and effectively [9]. So WhatsApp can provide effective in communicating, interacting easily and quickly, especially in conveying learning information.

Thus the researcher concludes that WhatsApp is an internet-assisted instant application, which is able to facilitate its use with the features presented. The use of WhatsApp has also become a communication tool that is widely used among the community because of its easy users, especially its use in learning. The year 2020 is the toughest year in various parts of the world, especially Indonesia. Coronavirus Diseases 2019 (COVID-19) is the name for a new virus given by the World Health Organization (WHO) that can spread quickly. On January 30, 2021, WHO has declared it a public health emergency that is troubling the world due to the spread of the coronavirus. The coronavirus outbreak has had a significant impact on various sectors, especially education [10].

Therefore, the government provides a policy to stay at home by conducting online learning activities for all elementary, middle, high school and college students. This is in accordance with the policy of Minister Nadiem Anwar Makarim who issued Circular Letter Number 4 of 2020 in Education units through the Circular Letter of the Minister of Education and Culture Number 36962/MPK.A/HK/2020 concerning online learning (on the network) in order to prevent the spread of Corona Virus Diseases (COVID-19) which stated that all indoor and outdoor activities in all sectors were temporarily postponed in order to reduce the spread of the coronavirus, especially in the education sector [11]. With the circular letter, the government implemented policies, namely social restrictions, social distancing and the use of masks. This is also supported by the issuance of SE No. 4 of 2020 regarding the implementation of education policies during the Covid-19 pandemic where the learning process can be carried out online or offline to provide meaningful learning experiences, provide a focus on life skills, as well as varied learning activities. According to the interests, conditions and facilities of students.

The online learning model has provided a new experience that is more challenging than conventional learning models (face to face). Unlimited learning time and place gives students the freedom to choose the right time in learning based on their interests, so that the ability to understand learning materials is higher than learning in class [12]. Online learning using online applications can increase learning independence. With the increasing attitude of independence of students in learning will make them responsible for the tasks that have been 
given, and be able to foster student interest in learning of the availability of attractive features and appearance provided by the application [13].

With the application of online learning in the midst of a pandemic, it will certainly change the role of teachers and the role of students in the learning process. Students must be able to adapt to the situation. The use of various forms of online learning media is certainly very helpful for students to access various information that is ready to be accepted by students. The learning is an educational innovation to answer the problem of the availability of more varied learning resources [14]. With the internet network students can act as researchers, even become analysts, and not only as consumers of information. Students and teachers do not need to meet physically in class, because students can study, teaching materials and do the tasks given by the teacher by utilizing internet access and even students can send messages to each other to discuss.

In the midst of the current pandemic, the learning process must still be carried out even though it is not face to face. This is where the role of educators is to be able to use social media, especially WhatsApp. This activity supports the application of learning in the 4.0 era that utilizes technology, a technology that can currently be accessed to get information very easily and can be done anytime and anywhere with the internet network, as well as finding the right solution to overcome the problems that occur in the middle of the world. Learning during the Covid-19 pandemic.

In connection with the current pandemic phenomenon, the use of media in networkassisted distance learning greatly assists the learning process, one of which is WhatsApp media. WhatsApp as a learning medium in the network during the Covid-19 pandemic. It needs to be reviewed more deeply regarding its implementation in various universities, one of which is at UIN Sulthan Thaha Saifuddin Jambi. Therefore, it can be concluded that the existence of WhatsApp is able to help communication systems, both long and short distances at a low cost and easy to use, not only in social life but also in learning activities. Even though WhatsApp has shortcomings, the existence of WhatsApp remains the most widely used and frequently used application, people still use it because it is considered to have more advantages.

Based on initial observations or observations made by researchers in the field, that in the process of implementing learning lecturers apply online learning systems with WhatsApp as a learning medium. This is in accordance with the information provided by the head of the institution stating that learning activities in the midst of the current pandemic, lecturers choose to use WhatsApp media, one of which is Arabic language lecturers who use WhatsApp (Group chat or personal chat) as a learning medium in the net (Online) and All learning processes while at home are centered on the use of WhatsApp, with this media it can help lecturers to be able to communicate with students and foster student independence during the online learning process (in the network).

From these initial findings, researchers will review how the process of learning Arabic in the network is implemented by higher education institutions, especially UIN Sulthan Thaha Saifuddin Jambi during the Covid-19 Pandemic. There are several problems faced by students, including unclear material, difficult pronunciation of sentences, inadequate smartphones, limited quotas and networks and lack of interest and motivation. With regard to the online learning media used in the form of WhatsApp media at UIN Sulthan Thaha Saifuddin Jambi, the researchers intend to conduct research in order to obtain accurate data and information related to the Arabic language learning process in the Covid-19 Pandemic Period Network at UIN Sulthan Thaha Saifuddin Jambi. 


\section{Methodology}

\subsection{Types of Research Methods}

This study uses a qualitative approach, in an effort to provide answers to the problems that have been described, because it uses descriptive analysis emphasis. In other explanation, this research is in the form of descriptions, describing an ongoing situation based on facts and information obtained from the field and then analyzed based on one variable with another as an effort to provide solutions regarding the implementation of online learning Arabic with the help of WhatsApp media during the pandemic at UIN Sulthan Thaha Saifuddin Jambi.

\subsection{Research Subjects}

The subjects of this study were Arabic language lecturers and students in the Arabic language education department in the even semester of 2020/2021 at UIN Sulthan Thaha Saifuddin Jambi. And the subject of data collection and informants in this study used purposive sampling. Purposive sampling, sampling deliberately in accordance with the required sample requirements.

\subsection{Data Collection Technique}

\subsubsection{Observation Method}

This observation technique is based on direct observation. This method is carried out by going directly into the environment where the research was carried out and by recording things that arise related to the required data information. The researchers used this method to observe directly the data in the field, especially about the data at UIN Sulthan Thaha Saifuddin Jambi. This method is used to reveal data which can directly observe things related to instilling religious values in the surrounding environment. Steps taken:

1. Observing the situation and conditions that occur.

2. Observing activities at UIN Sulthan Thaha Saifuddin Jambi during the covid-19 pandemic.

3. Observing the obstacles that exist in online learning with WhatsApp media at UIN Sulthan Thaha Saifuddin Jambi.

4. Paying attention to how the efforts/solutions are made by the lecturers, especially Arabic language lecturers face obstacles during the COVID-19 pandemic during online learning.

5. See the final results in online learning with WhatsApp media.

\subsubsection{Interview Method}

The interview is a form of verbal communication such as a conversation that aims to obtain information ". This interview method, researchers did to collect data, by conducting direct questions and answers with respondents and listening directly and carefully taking notes on what was explained by the respondent. This method is used to obtain data or information from several relevant data sources, namely, Arabic language lecturers, institutional leaders and students. Before the researcher conducted the interview, 
the researcher had prepared a set of questions related to the research. The research data included:

a. The use of WhatsApp media in learning Arabic online during the covid-19 pandemic at UIN Sulthan Thaha Saifuddin Jambi.

b. The obstacles that exist for students in using WhatsApp media to learn Arabic online during the COVID-19 pandemic at UIN Sulthan Thaha Saifuddin Jambi.

c. Lecturers' efforts in overcoming problems with online Arabic learning with the help of WhatsApp media during the covid-19 pandemic at UIN Sulthan Thaha Saifuddin Jambi

\subsubsection{Documentation Method}

Documentation method is a way of finding data on the ins and outs of research in the form of transcripts, books, newspapers, inscriptions, magazines, agendas and so on. These data include:

a. Profile of the Arabic Language Education Department at UIN Sulthan Thaha Saifuddin Jambi

b. History of Arabic Language Education Department at UIN Sulthan Thaha Saifuddin Jambi

c. Vision, Mission, Goals, Targets and Targets of the Arabic Language Education Department at UIN Sulthan Thaha Saifuddin Jambi

d. Arabic Language Education Department Curriculum at UIN Sulthan Thaha Saifuddin Jambi

e. The organizational structure of the Arabic Language Education Department at UIN Sulthan Thaha Saifuddin Jambi

f. The state of educators and education of the Arabic Language Education Department at UIN Sultan Thaha Saifuddin Jambi.

g. The condition of the students of the Arabic Language Education Department at UIN Sulthan Thaha Saifuddin Jambi

h. The state of facilities and infrastructure of the Arabic Language Education Department at UIN Sultan Thaha Saifuddin Jambi

\subsubsection{Data Analysis Technique}

In this study, what will be analyzed is through a qualitative approach using a deductive method. The deduction is a process of thinking by posing a specific problem. Data analysis includes:

a. Data Reduction, after reading, studying, then the next step is data reduction. Data reduction is a process of selecting, concentrating, paying attention to simplifying, abstracting, and transforming rough data that emerges from notes written in the field. Data reduction was carried out during the research.

b. Data Presentation, after going through data reduction, the next step is the presentation of data or a set of information that allows researchers to draw conclusions.

c. Verification/Withdrawal of Conclusions, after the collected data is reduced and then presented, the last step in the data analyzer is drawing conclusions or verification and analysis using interactive model analysis, meaning that this analysis is carried out in an interactive form from the three main components. 


\section{Results and Discussion}

\subsection{Implementation of the Online Arabic Learning Process with WhatsApp}

The process of learning Arabic online using WhatsApp media at UIN Sulthan Thaha Saifuddin Jambi has been carried out according to the policy issued by Minister Nadiem Anwar Makarim who issued Circular Letter Number 3 of 2020 in Education units through Circular Letter of the Minister of Education and Culture, Number 36962/MPK.A/HK/2020 regarding "Online Learning (On the Network) in order to prevent the spread of Corona Virus Diseases (COVID-19).

This policy is issued, forcing teachers and students to continue to carry out the learning process from home with the help of distance learning media, one of which is the use of WhatsApp used by Arabic language teachers, all learning activities are accessed through applications using quotas/WhatsApp.

The lecturers at UIN Sulthan Thaha Saifuddin Jambi agreed to choose the WhatsApp application as a learning medium from home, with the reasons why UIN Sultan Thaha Saifuddin Gambian students chose WhatsApp as a learning medium as follows: 1) The use of WhatsApp is not too difficult, it is proven that the majority of people from all walks of life use WhatsApp a lot. 2). Applications that have not too much space, so phones with belowstandard RAM capacity can use them. 3). And it doesn't take up much internet quote.

The online language learning process using WhatsApp media in the Arabic Language Education department at UIN Sulthan Thaha Saifuddin Jambi, which was carried out by lecturers for students during the covid 19 period, of course consisted of various businesses or activity steps that were adapted to the current Covid 19 conditions. Learning Arabic online with WhatsApp at the Arabic Language Education department at UIN Sulthan Thaha Saifuddin Jambi is:

a. WhatsApp group organization

The organization of online Arabic subjects with WhatsApp media uses several WhatsApp groups consisting of a WhatsApp group of Arabic lecturers, Arabic lecturers with students and a WhatsApp group of Arabic lecturers with parents of students. In addition to students, parents can also interact more easily with lecturers, both regarding assignments and children's development during learning activities at home. For the task delivery system, it can be done by sending it to the WhatsApp group.

b. Preparation for making Learning Planning online

Preparation for making online RPP, which is currently being implemented in the midst of the current pandemic. Where in the RPP we must design the learning process in such a way that the material to be delivered can be understood. Starting from preliminary activities, implementation (core) to closing. In the implementation activities carried out in this study, namely preparing material in the form of learning videos or photos, and material in the form of pdf or PowerPoint, then uploading the material into the WhatsApp group, then providing opportunities for students to ask if there are difficulties, students can directly send it via WhatsApp group or personal chat.

The efforts made by teachers in the COVID-19 pandemic must be able to arouse student activity both physically and mentally. Lecturers' efforts in improving student activities include efforts to activate the senses, reason, memory and emotions of their students. This effort requires lecturers to be able to understand the character of each student when studying and based on that understanding the lecturer can also create learning that is able to encourage 
students to think and act actively and creatively and is Arabic learning effective during this covid period? Even though through social media or not, face to face.

In carrying out online learning with various limited abilities, facilities and infrastructure in the form of cell phones, lack of interaction, difficulty knowing the seriousness of students, lack of interest in student learning, It is difficult to understand the material provided for lecturers and students as well as the limited abilities in the use of technology, so that the implementation of online learning must continue to be pursued so that the process of transforming the knowledge of learning Arabic online for students is not disrupted.

As various limitations in the COVID-19 pandemic situation, it becomes a challenge for lecturers and students to continue to want to learn to teach online. Besides that, lecturers must be able to present a fun learning so that learning is not monotonous or boring and can still present an interactive learning atmosphere between lecturers and students. It can be concluded that the process of learning Arabic online using WhatsApp media at UIN Sulthan Thaha Saifuddin Jambi during the covid 19 pandemic was very ineffective, but learning was still achieved even though there were many obstacles that interfered with distance learning such as the problem of social interaction between lecturers and students and the economy of participants. Students who are barely ready.

\subsection{Obstacles in the Process of Learning Arabic Online with WhatsApp}

In online learning with WhatsApp media there are obstacles experienced by students and lecturers so that learning does not run effectively. The obstacles that occur in the field include first mobile phone, second internet quota, third limited available time, lack of student interest, low student discipline. Online learning is a new thing for children, which is usually face-toface, now it is done online, independently at home for some students using their parents' or older siblings' cellphones, of course their use is limited and cannot access it all the time.

a. Mobile

For learning Arabic during the COVID-19 pandemic, mobile phones are needed and download the WhatsApp application as a medium in learning that is used at UIN Sulthan Thaha Saifuddin Jambi, because some students use their parents' or older siblings' cellphones, of course their use is limited and cannot access it at any time.

b. Internet quota

In the process of learning Arabic online using WhatsApp media at UIN Sulthan Thaha Saifuddin Jambi, students in addition, having a cell phone must also have an internet quota, if there is no quota, students also cannot participate in the online learning process.

c. The available time is very limited

Talking about time is the most valuable thing that must be used intelligently for teaching and learning at home, students must be wise in dividing which time to study from home and which time to play, so that time will be effective to use or useful. Students were not able to manage their study time well, so that the tasks that have not been done are piled up which in turn causes a feeling of laziness to do them.

d. Lack of interest in student learning

Student interest in learning decreases when entering a distance learning due to boredom in undergoing distance learning, both for educators and students. Although there is internet quota assistance from the Ministry of Education and Culture, the number of students participating in online learning through the WhatsApp application is decreasing day by day.

e. Low student discipline 
The school has determined an effective distance learning schedule that has been prepared for students, but there are still most students who are not disciplined in participating in learning and there are still many students who have not followed the learning schedule according to the schedule, so the tasks given by the lecturer are not done and collecting assignments from lecturers often do not match the allotted time.

\subsection{Efforts made by Arabic language lecturers to overcome obstacles in the online Arabic learning process with WhatsApp}

The efforts made by Arabic language lecturers are to provide solutions to related student guardians rather than the obstacles that have been experienced during the online Arabic learning process with WhatsApp media at UIN Sulthan Thaha Saifuddin Jambi, among others:

a. Because some students use their parents' or siblings' cellphones, of course their use is limited and cannot access them at any time. Then the lecturer provides solutions to students, the lecturer tells the person or the brother of the student to borrow a cell phone so that students can help learning, If it can't be done because there is only 1 cellphone or the parents and siblings are also in great need for various things, the lecturer must convey it to the parents or brother to be conveyed again to the students that at the time that has been set there is a lesson or task given to him either explanation or assignment.

b. The Ministry of Education and Culture, Nadiem Makariam said that there is free quota assistance to schools and colleges and lecturers also get free quotas then lecturers provide free quotas for connecting from the government to students of $42 \mathrm{~GB} / \mathrm{month}$. Free internet quota assistance is very helpful in the current situation.

c. The available time is very limited with a very short learning time, lecturers are required to make the best use of time. For this reason, if students do not use their time well, of course it will have an impact on themselves. That's the attitude of children that often occurs during online learning. Even though online classes are more limited in time than usual classes.

d. Students' interest in learning decreases, therefore lecturers can try to generate feelings of pleasure, order in students in learning, student attention and involvement. As an effort to enforce teaching and learning activities that are more fun or not boring.

e. Student discipline is still low, therefore lecturers can ask for help from students' parents because students' parents also play an important role in distance learning.

f. The learning process during the COVID-19 period will actually be carried out well if the facilities and infrastructure are met and evenly distributed. Lecturers are very influential in the Arabic learning process during the covid period, namely lecturers maximize existing resources and make learning plans that are easily accessible by students so that students are easy to learn and understand the material given by their lecturers. There are many ways that lecturers do, namely designing simple but meaningful or quality learning plans, making material that is easily accessible through electronic media such as video, PowerPoint, which can be sent via the WhatsApp application and making learning that has many variations so that students are not easily bored with learning. Continued at home, then the collection of assignments was also given a long time. Cellphone and network problems become an obstacle for students if the media used by lecturers are large in size. For example, lecturers can make video media and lecturers can make it in a short time and small in size so that students don't mind downloading or watching on their cellphones. If the video is too heavy, the lecturer can make learning media in the form of 
a PowerPoint file or the lecturer can send it via e-mail or WhatsApp application that is easily accessible by students.

\subsection{The results achieved in the process of learning Arabic online with social media WhatsApp}

The results of learning Arabic online using WhatsApp media in the Arabic language education department at UIN Sulthan Thaha Saifuddin Jambi, which were obtained during this covid 19 period, student scores greatly decreased because studying during the covid 19 pandemic was not effective, students had difficulty understanding Arabic learning given from the lecturer, students learn from their homes not really, lack of interest and motivation. When learning at home or online during this pandemic the role of lecturers and parents is very important and must work together in the teaching and learning process, so that students do not experience obstacles in learning, so that student learning outcomes do not decrease. Therefore, students must continue to obey the government's advice to stay and study at home. Therefore, lecturers and students will remain safe in their respective homes without having to meet face to face. There are still many students who have difficulty in the learning process, they even think that learning is very boring, the assignments pile up and the material given by the lecturer does not understand, so the learning outcomes of students will decrease.

"Student learning outcomes shows that not all students can undergo this online learning and student learning outcomes are not all achieved due to various factors such as cell phones, quotas, very limited time available, declining student and student interest in learning, student discipline. In learning is still low, the lack of lecturer guidance, so that the achievement of student learning outcomes is less than optimal."

During the COVID-19 pandemic, distance learning has an impact on student academic scores. When researchers evaluate at UIN Sulthan Thaha Saifuddin Jambi there are still many limitations because for one year, academically there will be a decrease in student learning outcomes, because after all the lecturers provide material, of course the total material is far below the normal situation when students study directly. Distance learning will affect students' academic scores. Because, when learning directly, students' understanding is still lacking, especially distance learning. Therefore, in the future the Ministry of Education and Culture has asked lecturers to be able to carry out assessments that are not only learning from the material or subjects. Lecturers are asked to be able to conduct assessments on the basis of not only the results of answering questions, but sincerity, motivation, discipline, students in participating in distance learning at home, it is also an assessment, it is part of character assessment as well. Learning as an online learning plan uses learning approaches and models to achieve learning objectives. The approach is to explain the material through video, students who go offline learn the material from the LKS, the method is that the lecturer makes a video explaining the material and then sends it via WhatsApp.

Then is the learning effective in achieving educational goals and does it not affect student learning outcomes? Learning through WhatsApp media is very different from direct learning. Those who usually study in a crowded atmosphere, can exchange information directly with friends, use the break after class or just eat together in the canteen. The atmosphere is very different from online learning. Where students are alone to do assignments and are given endless assignments. Things like this must greatly affect student learning outcomes, because the atmosphere is different, sometimes making students prefer to be lazy rather than doing assignments or discussing Fiqh learning with their friends. If this is the condition, the goals of education are difficult to achieve. 
In online learning, not all subject lecturers are creative in delivering learning, there are some educators who even directly give assignments in the book, without explaining in detail the material. This makes students confused. And the result is not doing the assigned task or the task is done by his parents. Then what is the role of parents in this? During a pandemic like this, parents must carry out their duties as a child's school. When online learning does not run smoothly, parents must take on the task of educators to educate their children. Because, as stated above, online learning is not as effective as direct learning.

There are so many things parents can do to support their children's academic grades. And of course it makes students less stressed and burdened by this online learning. As much as possible, accompany students when learning is carried out, so that students study seriously. Be a wise parent by not allowing students to ask for help in writing their assignments, either to their brother or sister. This also helps the formation of the character of responsibility to students, that if the task given to him must be completed by himself, but if it helps in teaching students it is okay. Cultivate discipline for students by always reminding students that when teaching and learning will start, they must be on time and remind them to do the assignments they receive and not procrastinate.

\section{Conclusion}

The Effectiveness of WhatsApp as a Learning Media in the Network during the Covid-19 Pandemic Period By an Arabic language lecturer at UIN Sulthan Thaha Saifuddin Jambi, the first is the process carried out by Arabic language lecturers in learning activities that include opening, core, and closing activities. Then the features that are often used are photos, videos, documents, WhatsApp groups, and direct calls. Ease is felt in the presence of the WhatsApp feature and also its easy use and can be used by various groups. As for the use of WhatsApp as a learning medium of the network during the Covid-19 pandemic, it can be conveyed as follows: (a) The use of WhatsApp with the use of existing features is very helpful in the learning process, but this implementation is less effective because not all of the material presented is well understood. Arabic language lecturers must fulfill their learning and teaching obligations so that the material can be delivered properly. (b) With the perceived obstacles, one of which was giving too many assignments and materials, the suggestions from the researchers of the material presented were further simplified so that they were easy to understand so that students would not get bored. (c) The need to increase teacher competence regarding the use of ICT, so that the readiness of learning activities using technology as it is today can be maximized. Obstacles in using WhatsApp as a learning medium in the network during the Covid -19 Pandemic at UIN Sulthan Thaha Saifuddin Jambi, namely signal interference which makes WhatsApp difficult to access, another obstacle is the ineffectiveness of the learning process for Arabic lecturers who cannot directly see the sincerity learners, Fast mobile memory is full of incoming documents, not all students have online learning support tools at this time, the reasons are the lack of trust in the given cellphone, lack of interaction between lecturers and other students, and learning using WhatsApp is also less effective because it does not All students understand the tasks and materials given. The solution to overcome obstacles in the use of WhatsApp as a learning medium of the network during the Covid -19 Pandemic at UIN Sulthan Thaha Saifuddin Jambi carried out by Arabic language lecturers was to minimize all obstacles, both from network disturbances by extending the delivery period of assignments, making learning materials simpler and easy to understand, 
Interact by making video calls or interacting once a week, according to the schedule for exchanging learning books, and innovating other media such as google classroom or zoom meetings but not leaving the main role of using WhatsApp.

\section{References}

[1] Wagner N, Hassanein K, Head M. Who is responsible for e-learning success in higher education? A stakeholders' analysis. Journal of Educational Technology \& Society. 2008 Jul 1;11(3):26-36.

[2] Hartini S, Misbah M, Dewantara D, Oktovian RA, Aisyah N. Developing learning media using online prezi into materials about optical equipments. Jurnal Pendidikan IPA Indonesia. 2017 Oct $17 ; 6(2): 313-7$.

[3] Chairunnisa S, Benedictus AS. Analysis of emoji and emoticon usage in interpersonal communication of Blackberry messenger and WhatsApp application user. International Journal of Social Sciences and Management. 2017 Apr 24;4(2):120-6.

[4] Bouhnik D, Deshen M, Gan R. WhatsApp goes to school: Mobile instant messaging between teachers and students. Journal of Information Technology Education: Research. 2014 Jan $1 ; 13(1): 217-31$.

[5] Annamalai N. How do we know what is happening in WhatsApp: A case study investigating preservice teachers' online activity. Malaysian Journal of Learning and Instruction. 2018 Dec $31 ; 15(2): 207-25$.

[6] Handayani D. The Effect of whatsapp application assisted pjbl model and zoom meeting on learning outcomes of capita selecta. International Journal of Chemistry Education Research. 2020;4(2):46-52.

[7] Ahmad S, Zulfikar T, Hardiana F. The use of Social Media Whatsapp Among English education students for solving thesis writing problems. Humanities \& Social Sciences Reviews. 2020 May 24;8(3):447-55.

[8] Hasan I, Ahmed SP, Ahmed SU, Yousuf TB. Factors influencing users' willingness for online messaging services: a developing country perspective. International Journal of Mobile Communications. 2021;19(1):75-98.

[9] Rahaded U, Puspitasari E, Hidayati D. The impact of Whatsapp toward uad undergraduate students' behavior in learning process. International Journal of Educational Management and Innovation. 2020 Jan 24;1(1):55-68.

[10] Al-Baadani AA, Abbas M. The impact of coronavirus (Covid19) pandemic on higher education institutions (HEIs) in Yemen: Challenges and recommendations for the future. European Journal of Education Studies. 2020 Jun 27;7(7).

[11] Suprapto Y, Rifai M, Faizah F, Setiawan A. The Role of Information Technology Knowledge and Online Learning on Learning Environmental Changes in Vocational Education. In2020 Third International Conference on Vocational Education and Electrical Engineering (ICVEE) 2020 Oct 3 (pp. 1-4). IEEE.

[12] Taylor ME, Boyer W. Play-based learning: Evidence-based research to improve children's learning experiences in the kindergarten classroom. Early Childhood Education Journal. 2020 Mar;48(2):127-33.

[13] Iatsyshyn AV, Kovach VO, Lyubchak VO, Zuban YO, Piven AG, Sokolyuk OM, Iatsyshyn AV, Popov OO, Artemchuk VO, Shyshkina MP. Application of augmented reality technologies for education projects preparation.

[14] Machado MS, Sepúlveda GC, Montoya MS. Educational innovation and digital competencies: the case of OER in a private Venezuelan university. International Journal of Educational Technology in Higher Education. 2016 Dec;13(1):1-0. 